\title{
SARAH Tran's InSPIRING OPTIMISM
}

\author{
Peter S. Menell*
}

$\mathrm{W}$

HEN I was invited to contribute to this memorial for Professor Tran, my initial reaction was that perhaps I was unworthy. I met Sarah only twice. We spoke a handful of times by phone. We exchanged several dozen emails. The grief that I feel over her tragic passing cannot compare to the profound loss that her children, spouse, parents, siblings, extended family, close friends, students, and full-time colleagues must be experiencing. Yet even our relatively brief and infrequent interactions revealed a truly inspiring life, an indomitable spirit, and a deeply caring soul. Sarah was such a vital person in the early blossoming of her family life and career. Her optimism, enthusiasm, drive, and passion to confront profound societal challenges left an indelible impression on me. I can only hope that my chronicle of our fleeting connection and collaboration contributes to the memory of Sarah's remarkable life and her enduring spirit.

Our first meeting three years ago began with a simple, gracious email Sarah sent on July 1, 2011:

\section{SUBJECT: SEEKING ADVICE}

Dear Professor Menell,

I started as an assistant professor of law at Southern Methodist University this past January and am still learning the ropes of the profession. Professor Anderson at Boalt mentioned to me that you and I share common interests in intellectual property and environmental law, a fairly rare combination. I am thoroughly impressed and inspired by your successes in academia and, if possible, would greatly like to speak with you for 15 minutes via telephone or in person to learn any insights you may have for a recent entrant into academia with similar scholarly interests. I am staying with family in the Bay Area for the next three weeks. I know you are extremely busy, so I greatly appreciate your time.

\section{Sincerely, Sarah Tran}

She had me at "rare combination" of "intellectual property and environmental law." I invited her for lunch on Wednesday.

Sarah responded enthusiastically, but apologized that Wednesday was "the only day this week that won't work for me as I have planned to take

* Koret Professor of Law and Director, Berkeley Center for Law \& Technology, University of California at Berkeley School of Law. 
my two kids to the Exploratorium then. Would it be possible for me to meet you right after one of your classes on Thursday or Friday?" I could see immediately that we would get along. I vividly recalled my own sons' wonder at the Exploratorium. Sarah's priorities resonated.

We met on Thursday, July 7th for lunch at Berkeley Law's newly opened Café Zeb. Sarah was brimming with enthusiasm and questions about balancing raising children with an academic career, combining intellectual property scholarship with environmental law scholarship, developing research proposals, and building a rewarding academic career. Since I did not know much about how she began in academia, she offered a brief biography. She had earned an undergraduate degree in civil engineering from UC-Berkeley, after which she worked as an environmental engineer in California and as a Peace Corps volunteer in Guinea, West Africa. She made her way to Georgetown University Law Center, where she excelled academically, worked as a legal extern at Resources for the Future, and gained other valuable experience in the environmental law field. She then clerked for the Honorable Timothy Dyk on the U.S. Court of Appeals for the Federal Circuit, which expanded her knowledge of and interest in patent law. Her academic interests and passions spanned administrative law, environmental law, and patent law. Along the way, Sarah noted that she had married and had two wonderful children, ages six and one at the time of our lunch. She also mentioned that she was a cancer survivor brought back to life as a result of a bone marrow transplant from her brother. She had accomplished much and overcome a lifethreatening disease by her early thirties. Her horizons seemed limitless as she set about taking on the next phase of her journey.

As I reflect on that lunch three years ago, I recall what a pleasure it was to talk with a vibrant young scholar with such enthusiasm for life, family, and ideas. Our conversation began with the challenges of combining family life with an academic career. Like Sarah, I had started raising a family well before the tenure stage, and I was able to offer advice about using the flexibility of the academic schedule to be deeply involved in raising children during their waking hours while working hard-many late nights-to pursue research. I told Sarah that it was not easy, but greatly rewarding. I shared my own experience raising two wonderful sons-one who was in college and the other who was about to leave the nest on his college journey-and expressed my belief that academia provides an incomparable opportunity to have the best of both family and professional life. Sarah was encouraged and expressed hope to find such a balance.

As the conversation turned to academic life, Sarah wondered why there were relatively few scholars working at the intersection of intellectual property law and environmental law. I surmised that it reflected several factors: these practice areas had historically been distinct; many environmental scholars were attracted to public interest law, whereas many intellectual property scholars were drawn to technology and private 
ordering; and there were not a lot of legal academics with technology backgrounds. Sarah's questions prompted me to trace my own path into the intellectual property/environmental law fold.

The environmental prong came first. From the café where we were sitting, I pointed across the Bay and recalled my first trip to Muir Woods and Sausalito, a quaint artist enclave, when I was fourteen years old. For a kid raised in an uninspiring part of New Jersey, California's natural beauty was an epiphany. Over the next several years, Rachel Carson, John Muir, Wallace Stegner, Edward Abbey, and Frances Moore Lappé captured my imagination and shaped my aspirations. Regular pilgrimages to Yosemite, Big Sur, and Lake Tahoe and bike rides through the California hills during graduate school would seal my environmental passion. The opportunity to work with Professor Richard Stewart in law school supplied the professional mentorship needed to combine resource economics, comparative institutional analysis, and environmental policy. ${ }^{1}$

The intellectual property strand was more serendipitous. I was drawn to electronics and computers early in life, and computer programming became useful in college and graduate school. The disappointment of desiring, but not being able to afford, an IBM personal computer during graduate school sparked my curiosity in intellectual property law. From computer magazines, I had become aware that IBM did not manufacture the components in their microcomputer but instead purchased them from other vendors. When IBM began selling the chassis and main boards for their microcomputer to university students at a steep discount, I was able to assemble an IBM compatible PC using the same components as IBM but at about half the cost. To a graduate student studying microeconomic theory, industrial organization, and antitrust policy, this price differential did not make much sense. I traced the source of IBM's extraordinary market power to copyright protection over the Basic Input/Output System (BIOS) firmware interface-not a particularly innovative piece of the overall computer architecture, but a requirement for interoperability. I came to see that expansive copyright protection for computer software could undermine both rapid innovation and network externalities. ${ }^{2}$ Exposure to intellectual property cases during my clerkship deepened my interest.

One thing led to another, and I soon had several intellectual property papers and was being invited to serve on government commissions assessing intellectual property issues in the digital age. I found myself teaching near Silicon Valley as the software industry was skyrocketing and the Internet was about to reshape the economy and society. These experiences

1. Dick invited me to collaborate on a casebook just as I was embarking on my academic career. See Peter S. Menell \& Richard B. Stewart, Environmental Law \& Policy (1994).

2. See Peter S. Menell, Tailoring Legal Protection for Computer Software, 39 STAN. L. REV. 1329 (1987). 
led me to lay the groundwork for the Berkeley Center for Law \& Technology (BCLT) before the tenure stage.

Ironically, just as my environmental law casebook with Dick Stewart reached fruition, I was being pulled deeper into intellectual property, coauthoring casebooks in that field ${ }^{3}$ and developing new courses and curricula. Nonetheless, I continued to keep a hand in environmental law and policy work. As awareness of the threat of climate change emerged, I worked to co-found Berkeley's Energy and Cleantech Program.

I explained to Sarah my view that academic scholars need to be adaptable and versatile. I pulled out my favorite inspirational quotation from hockey great Wayne Gretzky: "A good hockey player plays where the puck is. A great hockey player plays where the puck is going to be." Similarly, successful legal academics need to combine a strong foundationwhich includes looking beyond the legal discipline to history, social science, and whatever else (technology) the research requires-with diligence and an ability to foresee where the puck is going. This is especially true in dynamic fields like intellectual property and environmental law.

Our conversation shifted to Sarah's research. She described her analysis of the U.S. Patent and Trademark Office (PTO) initiative to expedite patent applications in the cleantech field. ${ }^{4}$ I commended her identification of an interesting project that drew on her background in environmental, administrative, and intellectual property law. But as academics are wont to do, I pushed her a bit on an implicit premise: that patents are the primary or best mechanism for promoting innovation and adoption of green technologies. I noted the irony that unlike conventional innovation contexts where the United States sought to protect its technology from appropriation by other nations, the United States would want to encourage other nations to adopt green innovations as soon as possible to stem climate change. Perhaps patents, which rely principally on exclusion, were not the ideal innovation mechanism for cleantech.

Sarah was intrigued by this dual externality problem, and we proceeded to have a fascinating conversation about the subtleties. I encouraged her to avoid thinking about patents as "the" solution to innovation problems but rather as one of the potential solutions to innovation problems. I emphasized the importance of comparative institutional analysis and offered to serve as a tour guide into this multidisciplinary field. I also encouraged her to remain open to new ideas as she deepened her knowledge of foundational literature.

Our conversation shifted to the tremendous need and opportunities to better understand how law, markets, and other institutions could promote the technological advances required to surmount climate change. I men-

3. Robert P. Merges, Peter S. Menell, Mark A. Lemley, \& Thomas M. Jorde, INTELlectual Property in tHe New Technological Age (1st ed., 1997); Mark A. Lemley, Peter S. Menell, Robert P. Merges, \& Pamela Samuelson, Software And InTERnet Law (2000).

4. See Sarah Tran, Expediting Innovation, 36 Harv. EnvtL. L. Rev. 123 (2012). 
tioned Thomas Friedman's then-current book Hot, Flat, and Crowded as an example of the broad thinking that is needed to refocus the debate. Sarah had not yet read Friedman's tour de force. While commending the book for its analysis of geopolitics, emphasis on energy taxation, and insights into other aspects of the climate change challenge, I pointed out that it did not make a single mention of patents or intellectual property. I suggested that although intellectual property was a part of the larger innovation ecosystem affecting global climate change, the normative effects were ambiguous and ripe for further exploration. ${ }^{5}$ As I headed off to meet with research assistants, I expressed my hope that we would stay in contact.

My initial impressions of Sarah's thoughtfulness, passion, and excitement about the journey ahead were reinforced by the email that arrived the next day:

\section{SUBJECT: THANK YOU}

Dear Professor Menell,

I greatly enjoyed meeting you yesterday. I asked you for 15 minutes of your time, and you gave me far more. Our conversation has helped me formulate a clearer understanding of my research agenda and role as an academic with the ability to contribute to improving law and policy. Thank you. I also followed your advice and ordered a copy of Friedman's book. I look forward to reading it soon.

Sincerely,

Sarah

I was glad to find a kindred academic traveler, and I looked forward to the next opportunity that our paths might cross.

A month later, Sarah wrote:

\section{SUBJECT: EXCITING NEWS}

Dear Professor Menell:

I hope you had a great experience at the IPSC.

I'm writing to share some good news with you. I sent out my article, "Administrative Law, Patents, and Distorted Rules," for publication recently, and it was accepted by the George Washington Law Review

5. As I write this memorial tribute three years later, I note the debate triggered by Elon Musk's recent announcement that Tesla was "opening up" its patents to anyone who uses them "in good faith." See Jeffrey Hirsch \& Tiffany Hsu, Elon Musk Opens Up Tesla Patents to Everyone, L.A. Times (Jun. 12, 2014) http://www.latimes.com/business/autos/lafi-tesla-open-source-20140613-story.html\#page=1; Nicholas Thompson, Who Shared the Electric Car?, The New YORKer (June 13, 2014) http://www.newyorker.com/online/blogs/ currency/2014/06/elon-musk-shares-tesla-patents.html. It remains to be seen whether this gambit will work out, but it reveals the complex economics, business strategy, and public policy surrounding the role and use of intellectual property protection in cleantech markets. 
yesterday! I am very excited. Although I still have several days to accept this offer, I feel extremely pleased with this placement.

My discussion with you over the summer has had a tremendous, positive impact on me. I keep asking myself, "What will I contribute to the legal profession?" I believe that reflecting on this question helped me write a stronger article, and, more importantly, I feel like I have a much better sense of my scholarly purpose. Thank you so much for your mentorship.

All the best,

Sarah

It warmed my heart to receive such a gracious note. I expressed my congratulations. We continued to correspond through the end of the year about various academic and career issues.

Toward the end of 2011, I faced a looming deadline from a publisher that led me to think about Sarah. The prior spring, Edward Elgar Publishing had approached me about assembling a volume of articles around the theme of "Intellectual Property and the Environment" for its Critical Concepts in Intellectual Property Law series. I had several reservations about taking on the project and promised to get back to Elgar by the end of the year.

My concern about the project mirrored my conversation with Sarah six months earlier: avoiding the trap of seeing intellectual property law as "the" solution to all innovation problems. I worried that a volume that focused too narrowly on intellectual property and the environment would reinforce this overly narrow perspective. While I believed that intellectual property had an important role to play in addressing environmental protection, conservation, and renewable energy, I felt the project needed to encompass the full range of alternative innovation mechanisms as well as the limitations of intellectual property as a tool for promoting environmental protection. This struck me as a great opportunity to serve as a mentor to Sarah, just as Dick Stewart had done for me at the outset of my career. I saw our collaboration as an opportunity to explore and compile a broad collection of literature on intellectual property and the environment. In addition, we would co-author an introductory chapter that could serve as a roadmap for future scholars.

On January 26, 2012, I sent Sarah the following email:

\section{SUBJECT: IP, INNOVATION, AND THE ENVIRONMENT- POSSIBLE PROJECT}

Sarah-I wanted to run something of possible interest by you. Let me know if you have a few minutes to chat.

\section{Peter}

She replied later that morning that she could talk that afternoon. I invited her to co-edit/co-author the Elgar volume. I noted that on the bene- 
fit side, this project would provide a great opportunity to explore the broader landscape that I had mentioned the previous summer. But I also noted that I did not want to distract her from other important projects and that co-authored projects might not earn her the same recognition in tenure evaluation. She expressed strong enthusiasm. Nonetheless, I suggested that she chat with colleagues about how such a project would be perceived. We spoke again early on February 7 th, and she enthusiastically accepted. I mentioned that the only impediment for me was persuading the publisher to expand the subject matter of the book beyond "intellectual property" to encompass the range of innovation mechanisms. I expressed that I did not expect that to be a problem and suggested that we begin scouring the literature. I received the following email later that morning:

\section{SUBJECT: RE: [EDWARD ELGAR PUBLISHING] INTELLECTUAL PROPERTY AND THE ENVIRONMENT.}

\section{Dear Peter:}

It was a pleasure speaking with you today. However, I felt like I was a bit out of sorts when we spoke. I taught the late night shift last night, which means I left class at $10 \mathrm{pm}$ after answering student questions, and was woken up long before the sun rose by our kids. I'm feeling the effects of sleep deprivation today.

I'm really quite excited about this project and love your ideas! Having conversations like the one we had today about identifying the "big picture questions" is precisely the kind of mentorship I need at this early stage of my career, and I'm grateful for this opportunity. I will send you my list of articles soon.

Kindest regards,

Sarah

I could relate to the sleep deprivation of young parenthood. Sarah's dedication to her family, students, and research was inspiring. I was very much looking forward to collaborating with her on this project and possibly others.

The publisher was amenable to the expanded focus for the project and the addition of Sarah as co-author. The project would proceed in two phases: canvassing the vast literature relating to intellectual property, innovation, and the environment and developing an introductory chapter for the volume synthesizing the field. Since Sarah was planning to spend the summer in the San Francisco Bay Area, we agreed to postpone phase two until we would be in closer proximity. I suggested that we each assemble bibliographies of articles and books.

Within a few weeks, we had compiled extensive bibliographies and were actively corresponding about the larger project as well as possible spinoffs. In April, Sarah suggested that we submit a proposal to organize a "crosscutting" session on "Intellectual Property, Innovation, and the 
Environment" for the 2013 AALS Annual Meeting. I applauded her initiative and offered to help.

In early May, Sarah wrote to say that her summer plans had shifted as a result of her brother experiencing a stroke. Consequently, she planned to spend the summer with him in Arizona instead of living in the Bay Area. She assured me that this would not affect our project. I communicated that she should not worry about our academic project; her family came first.

Sarah was able to get to the Bay Area for a brief trip in early June, and we met to discuss the edited volume project. She dutifully sent me a rough outline as well as the following agenda:

(1) How should we organize the introduction;

(2) Are there any themes by which we want to select or organize the articles;

(3) Should we set deadlines for selecting articles; and

(4) How much discussion of the dual externality problem do we want to include in the introduction?

We met for about 90 minutes in Berkeley and mapped out the structure for the volume. It was clear from our respective lists that Sarah was aware of recent literature but was not familiar with the foundational writings on innovation and the environment. She was also unsure how to frame the larger picture. We discussed major thematic elements and alternative organizational approaches. I was greatly encouraged by the breadth of our bibliography and the ease of talking through the issues.

Following the meeting, I sent Sarah the introduction to a prior book that I edited on environmental law 6 and encouraged her to read some of the classic articles on innovation and the environment, including one written by my law school mentor. ${ }^{7}$ Over the next several months, we corresponded about the articles and how best to capture the interplay of intellectual property, innovation, and the environment. We informed our publisher that we would complete the project by year end.

Sarah's cancer returned in the fall. I was so sorry to hear this news and suggested that I would take responsibility for getting the volume completed. Sarah would hear nothing of it. She was full of hope and wanted to proceed as though nothing had changed. She told me that she was continuing to teach her classes, Skype-ing into the SMU classroom from her hospital bed. Her courage, optimism, and fortitude were remarkable. When we talked by phone or corresponded by email, Sarah remained focused on completing our project and undertaking future projects. I interpreted these expressions as positive signs about her treatment. Sarah reminded me that she had beaten cancer before and would do so again. Her inner strength and resolve were inspiring.

6. See Peter S. Menell, Environmental Law (The International Library of Essays in Law and Legal Theory (Second Series)) (2002).

7. See Richard B. Stewart, Regulation, Innovation, and Administrative Law: A Conceptual Framework, 69 CALIF. L. REv. 1256 (1981). 
We completed the volume by mid-December and submitted it to the publisher two weeks ahead of schedule. The volume was divided into five parts:

I. Historical Perspective: Promoting Innovation in Pollution Control Through Regulation and Market-based Instruments

II. Intellectual Property as an Environmental Policy Tool: Conceptual Foundations

III. Using Intellectual Property to Promote Environmental Protection

IV. Intellectual Property and Concerns about Diffusion of Improved Environmental Protection Technologies

V. Complements and Alternatives to Intellectual Property for Stimulating Advances in Environmental Protection Technologies

The volume spanned classic research on "technology forcing"8 (including Dick Stewart's seminal articles ${ }^{9}$ ), economic analysis of market failure, ${ }^{10}$ the role of patents in promoting innovation (including Sarah's article on expediting innovation), ${ }^{11}$ drawbacks of intellectual property protection for diffusion, ${ }^{12}$ and other mechanisms for promoting environmental protection. ${ }^{13}$ It spanned historical, descriptive, analytical, comparative-institutional, and empirical scholarship. I could not have been more pleased with the intellectual breadth of the volume and synthesis of the introductory chapter. Sarah spoke encouragingly about building on this project.

8. D. Bruce La Pierre, Technology-Forcing and Federal Environmental Protection Statutes, 62 Iowa L. REv. 771 (1977).

9. Bruce A. Ackerman and Richard B. Stewart, Reforming Environmental Law: The Democratic Case for Market Incentives, 13 Colum. J. ENvTL. L. 171 (1988); Stewart, supra note 7.

10. Adam B. Jaffe, Richard G. Newell \& Robert N. Stavins, A Tale of Two Market Failures: Technology and Environmental Policy, 54 ECOLOGICAL ECON. 164 (2005).

11. Natalie M. Derzko, Using Intellectual Property Law and Regulatory Processes to Foster the Innovation and Diffusion of Environmental Technologies, 20 HARV. ENVTL L. Rev. 3 (1996); Michael A. Gollin, Using Intellectual Property to Improve Environmental Protection, 4 HaRv. J.L. \& TECH. 193 (1991); Tran, supra note 4.

12. Jorge L. Contreras, Standards, Patents, and the National Smart Grid, 32 PACE L. Rev. 641 (2012); Bronwyn H. Hall \& Christian Helmers, The Role of Patent Protection in (Clean/Green) Technology Transfer, 26 Santa Clara Computer \& High Tech. L.J. 487 (2010); Eric Lane, Clean Tech Reality Check: Nine International Green Technology Transfer Deals Unhindered by Intellectual Property Rights, 26 Santa Clara Computer \& High TeCH L.J. 533 (2010); Eric Lane, Keeping the LEDs On and the Electric Motors Running: Clean Tech in Court after eBay, 2010 Duke L. \& TECH. Rev. 13 (2010); Joshua D. Sarnoff, The Patent System and Climate Change, 16 VA. J.L. \& TECH. 301 (2011); Jason R. Wiener, Sharing Potential and the Potential for Sharing: Open Source Licensing as a Legal and Economic Modality for the Dissemination of Renewable Energy Technology, 18 Geo. Int'l Envtl. L. Rev. 277 (2006): John H. Barton, ICTSD Trade \& Sustainable Energy Series Paper No. 2, In''L CTr. for Trade \& Sustainable Development (2007), Intellectual Property and Access to Clean Energy Technologies in Developing Coun. tries: An Analysis of Solar Photovoltaic, Biofuel and Wind Technologies.

13. Jonathan H. Adler, Eyes on a Climate Prize: Rewarding Energy Innovation to Achieve Climate Stabilization, 35 Harv. EnvtL. L. Rev. 1 (2011); Gary E. Marchant, Sustainable Energy Technologies: Ten Lessons from the History of Technology Regulation, 18 WIDENER L.J. 831 (2009). 
The publisher indicated it would take some months to obtain the needed copyright permissions. Over the next several months, Sarah and I refined the introduction based on suggestions from scholars and practitioners. Sarah remained upbeat about her medical treatment.

I was also greatly encouraged by Sarah's circulation of an article exploring the ramifications of the social media revolution for political institutions and political economy theory. ${ }^{14}$ Using insights and examples from social media platforms like Twitter, Sarah illustrated how traditional theories of agency capture needed to be updated and augmented to reflect changing costs of social organization and citizen activism. This article showed tremendous range, balance, and ambition.

Sarah contacted me as she was receiving responses from law reviews. We talked about how she had found a rich new mineral vein to explore. She expressed her gratitude for my encouraging her to think boldly and ambitiously. Her excitement about the project was palpable. It was thrilling to see a young scholar gaining the confidence to spread her wings and fly. She could now see far ahead to a bright academic career.

In August 2013, we received word that all of the copyright permissions had been approved and that the volume was headed into final production. We dealt with page proofs and minor editing through the fall. On December 12, 2013, Sarah wrote:

\section{SUBJECT: RE: INTELLECTUAL PROPERTY, INNOVATION AND THE ENVIRONMENT}

Dear Peter:

I hope your holiday season is off to a great start. Do you have any winter plans?

I've reviewed the project, and the only thing I noticed was that on the Acknowledgments page, first sentence, it says "copyright material" rather than "copyrighted material." Although I've only heard the term "copyrighted material" before (and a quick google search confirmed this is the more common phrase), I wasn't sure if the terms were interchangeable or whether in the UK they do things a little differently. Any thoughts before I mention this point to Harry?

It has been a real pleasure working with you on this, and it seems amazing that we are so close to the finish line.

Best,

Sarah

"Amazing" was an understatement in this context. Over the arc of the project, Sarah had battled cancer while raising young children, maintaining her teaching, and producing an impressive range of scholarship. I was relieved to get such a mundane (dealing with a minor editorial matter)

14. Sarah Tran, Cyber-Republicanism, 55 WM. \& MARY L. REv. 383 (2013). 
and hopeful note from Sarah. I sent in my editorial changes and looked forward to building on this successful collaboration.

On February 4, 2014, we received an email from the publisher confirming that our book was nearly ready for shipping and inquiring whether the listed addresses for Sarah and me were correct for sending our copies and the modest editors' fee. Sarah replied moments later:

Subject: Re: Your title: Intellectual Property, Innovation and the Environment

To: Jennie Hawdon

cc: Peter S. Menell

Wonderful! Yes, my address is correct.

Best,

Sarah

Several weeks later, I received an ominous phone message on my office voicemail. My heart sank when the caller mentioned that he was from SMU. I promptly called him back and learned the tragic news of Sarah's passing. My initial reaction was disbelief. Sarah had sent our publisher and me an upbeat email just weeks ago. Sarah's colleague explained that this might have been one of the last emails she sent. I realized that part of Sarah's strength manifest in her ability to shield those around her from the disease tormenting her.

When our published volume ${ }^{15}$ arrived a short time later, I experienced a complex mix of emotions. Sarah never had the opportunity to hold the volume in her hands.

As I reflect on what Sarah left behind, I am inspired by her courage, strength, passion for life, indomitable spirit, and optimism. Paraphrasing Sarah's email just three years ago:

Subject: Thank you

Dear Sarah,

I have greatly appreciated the opportunity to know and work with you. I invited you to collaborate on a project, and you gave me far more ....

Peter

15. See Peter S. Menell \& Sarah M. Tran, Intellectual Property, InNovation And The Environment (2014). 


\section{The 2014 SMU Criminal Justice Colloquium}




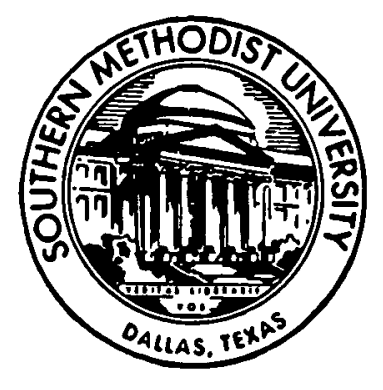




\section{Foreword}




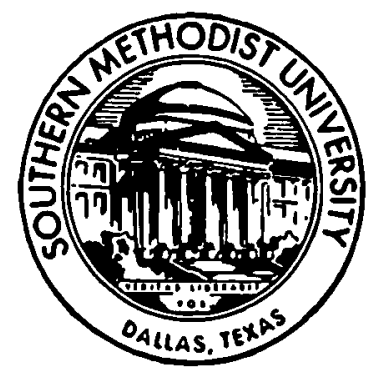

